\title{
A case of probable oxybutynin-induced increase in liver enzymes
}

This article was published in the following Dove Press journal:

Therapeutics and Clinical Risk Management

\author{
Haneen Alrawashdeh' \\ Lama Madi \\ Arwa Hassan Ahmed \\ Elhada' \\ Afif Ahmed' \\ Dhiaddin Serheed ${ }^{3}$ \\ 'Department of Pharmacy, Women \\ Wellness and Research Center, Hamad \\ Medical Corporation, Doha, Qatar; \\ ${ }^{2}$ Department of Pharmacy, Qatar \\ Rehabilitation Institute, Doha, Qatar; \\ ${ }^{3}$ Department of Physical Medicine and \\ Rehab, Qatar Rehabilitation Institute, \\ Doha, Qatar
}

\begin{abstract}
We describe the case of a 49-year-old male who presented to the emergency department with right-sided weakness and inability to speak. He was diagnosed with stroke and was admitted to Qatar Rehabilitation Institute after he was treated for the acute phase at Hamad General Hospital. As part of his management, he was started on oxybutynin $5 \mathrm{mg}$ orally twice daily for the treatment of overactive bladder. Within a week, his liver enzymes started to increase. After a thorough medication review, oxybutynin was suspended as it was the only suspected medication to be responsible of this elevation in liver enzymes. When Naranjo Adverse Drug Reaction Probability Scale was used to assess the probability of an adverse drug reaction (ADR), a score of 6 was obtained indicating a "Probable" ADR. In conclusion, this is the first published report of oxybutynin-induced elevation in liver enzymes. Further reports are required to highlight this probable ADR and alert all health professionals about it.
\end{abstract}

Keywords: oxybutynin, liver enzymes, alanine aminotransferase, aspartate aminotransferase, adverse drug reaction, liver injury

\section{Introduction}

Urinary incontinence (UI) after stroke has serious impacts on the individual's function outcome and mortality. It has a prevalence ranging from $32 \%$ to $79 \%$ on admission and $25 \%-28 \%$ at discharge ${ }^{1,2}$ Urge, functional, and stress incontinence are post-stroke UI disorders which can be improved by occupational and physical therapy interventions. ${ }^{3,4}$ In patients with bladder incontinence who do not respond to nonpharmacological intervention such as scheduled voiding and tailored fluid restriction, antimuscarinic medications are the gold standard of pharmacological therapy, of which oxybutynin is an example. . $^{5} 6$

Oxybutynin has a direct antispasmodic effect and inhibits the muscarinic action of acetylcholine on smooth muscle. ${ }^{7}$ The drug has an elimination half-life of 2-5 hours and is eliminated through liver due to it is low concentration in urine. ${ }^{8}$ Common adverse effects of oxybutynin include dry mouth, blurred vision, somnolence, constipation, and delirium. ${ }^{9}$

An increase in liver enzymes is considered significant when both alanine aminotransferase (ALT) and aspartate aminotransferase (AST) are 2-3 times higher than the baseline. The prevalence of abnormal liver enzyme was $10 \%$ in United States according to The National Health and Nutrition Examination Survey. ${ }^{7}$ Coagulopathy and alteration in the mental status may result from rapid deterioration of the liver function in a previously healthy individual. Moreover, acute liver failure may affect young people and result in death. ${ }^{8}$
Correspondence: Haneen Alrawashdeh Hamad Bin Khalifa Medical City (HBKMC), P.O. Box 3050, Doha, Qatar Tel +9744026I 680 Email halrawashdeh@hamad.qa hy
hereby accept the Terms. Non-commercial uses of the work are permitted without any further permission from Dove Medical Press Limited, provided the work is properly attributed. For permission for commercial use of this work, please see paragraphs 4.2 and 5 of our Terms (https://www.dovepress.com/terms.php). 
Liver injury might occur because of using several medications. The incidence of drug-induced liver injury has been reported to be between 10 and 15 per 10,000-100,000 persons exposed to prescription medications., ${ }^{910}$ The National Institute of Health developed a searchable database "LiverTox" that links medications, herbs, and dietary supplements to liver injury. ${ }^{11}$

Oxybutynin-induced increase in liver enzymes has never been reported before; a search of the "LiverTox" database failed to identify any report. ${ }^{12}$ Moreover, a search in the Canadian adverse drug reaction monitoring database has not identified any report. ${ }^{14}$ Furthermore, a search conducted in different databases (Medline, Embase, and Cumulative Index of Nursing and Allied Health Literature) in August 2017 did not identify any related reports.

This case report represents our experience of increased liver enzymes due to the use of oxybutynin for the management of UI in a stroke patient.

\section{Case presentation}

This is a 49-year-old male with hypertension and chronic kidney disease. He presented to the Emergency Department on the 28th of March 2017 with right-sided weakness and inability to speak. He was found to have recent acute/early subacute infarct along left middle cerebral artery territory.

On 6th of April 2017, the patient was transferred to Qatar Rehabilitation Institute to be enrolled in an active rehabilitation program. Upon assessment, he was found to have global aphasia, dense right-sided weakness, maximally assisted in bed mobility and transfer, and totally assisted in activities of daily life.

During his hospital stay, he had episodes of elevated liver enzymes and the suspected medications (atorvastatin $40 \mathrm{mg}$ orally daily and escitalopram $20 \mathrm{mg}$ orally daily) were suspended with continuous monitoring of the liver enzymes. Liver enzymes started to decrease within few days after the suspension but did not reach the baseline. A week after suspending escitalopram, he was started on (oxybutynin $5 \mathrm{mg}$ orally twice daily) for overactive bladder. Within a week of starting oxybutynin, liver enzymes increased again (Figures 1 and 2). A thorough medication review was done by the assigned clinical pharmacist and none of his medications was known to result in high liver enzymes. After discussing this with the physician, oxybutynin was the only suspected medication to be responsible of this elevation in liver enzymes as it was the newest medication added to his therapy, and hence, it was suspended.
ALT and AST levels during hospital stay

\begin{tabular}{|c|c|c|}
\hline Date (month/day/year) & ALT (U/L) & AST (U/L) \\
\hline $28 / 3 / 2017$ & 44 & - \\
\hline $28 / 3 / 2017$ & 25 & 22 \\
\hline $30 / 3 / 2017$ & 22 & 17 \\
\hline $7 / 4 / 2017$ & 261 & 122 \\
\hline 9/4/2017 & 445 & 207 \\
\hline $12 / 4 / 2017$ & 487 & 193 \\
\hline $16 / 4 / 2017$ & 398 & 140 \\
\hline $17 / 4 / 2017$ & 350 & 118 \\
\hline $20 / 4 / 2017$ & 178 & 52 \\
\hline $23 / 4 / 2017$ & 287 & 117 \\
\hline $25 / 4 / 2017$ & 358 & 139 \\
\hline $29 / 4 / 2017$ & 334 & 108 \\
\hline $2 / 5 / 2017$ & 238 & 56 \\
\hline $6 / 5 / 2017$ & 142 & 51 \\
\hline $13 / 5 / 2017$ & 203 & Hemolyzed \\
\hline $20 / 5 / 2017$ & 98 & 38 \\
\hline
\end{tabular}

Figure I Liver enzymes levels during hospital stay.

Notes: On 7/4/2017, atorvastatin was suspended and mild decrease noted. When liver enzymes started to increase again, on 26/4/2017, escitalopram was suspended and they started to lower after few days. Oxybutynin was started on $6 / 5 / 2017$, and the enzymes elevated again within a week. On 15/5/2017, oxybutynin was suspended and, in few days, a decrease in liver enzymes was noted.

Abbreviations: ALT, alanine aminotransferase; AST, aspartate aminotransferase.

To rule out inflammatory, autoimmune, or any other underlying causes, the gastroenterology team was consulted to evaluate the case. Their primary assessment was "druginduced hepatitis." Their recommendations were to stop any suspected hepatotoxic medication and to do further investigations. These included full workup of hepatitis, hepatitis A virus immunoglobulin $\mathrm{M}$, hepatitis $\mathrm{C}$ virus antibody, hepatitis E virus immunoglobulin $\mathrm{M}$, antinuclear antibody, anti-smooth muscle antibody, antimitochondrial antibody, anti-liver kidney antibodies, and celiac profile - immunoglobulin A, anti-tissue transglutaminase antibodies, ceruloplasmin, and $\alpha-1$ antitrypsin. All the required tests were negative and the ultrasound of the abdomen showed normal findings. Within a week of discontinuing oxybutynin, both ALT and AST were decreased to values lower than 3 times the baseline.

As the patient was lost to follow-up, consent for publication of this case was not possible. However, the case details 


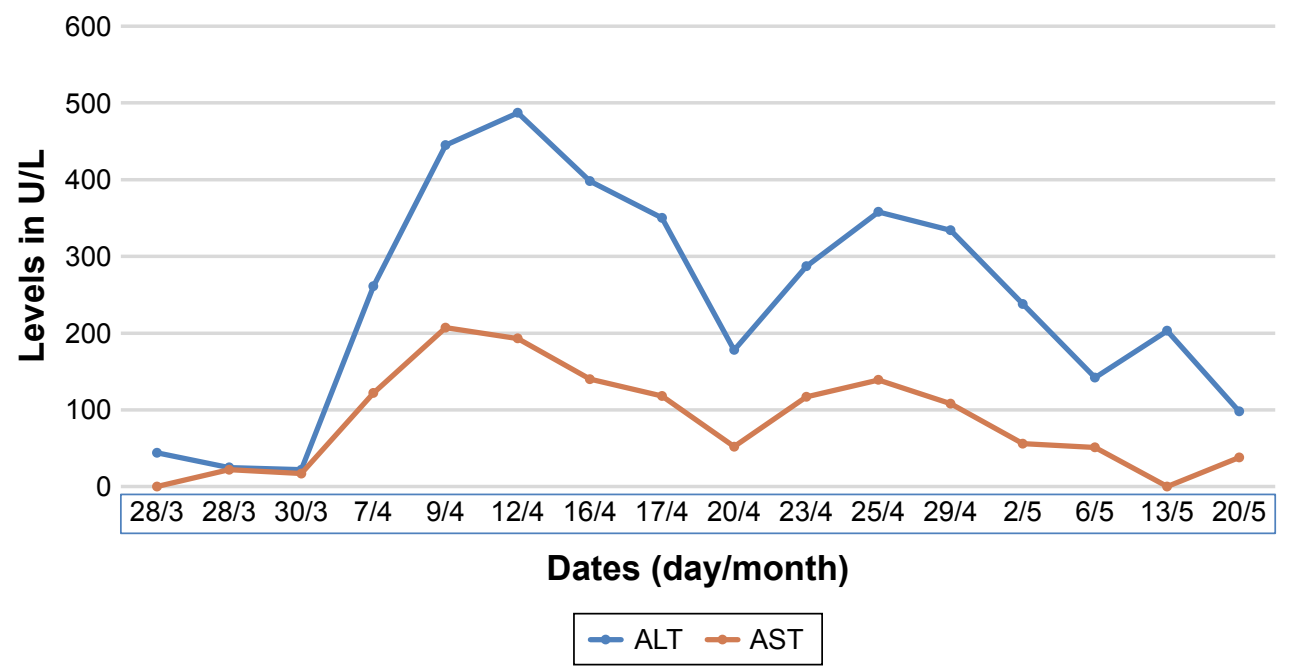

Figure 2 ALT and AST levels during hospital stay.

Notes: After suspending atorvastatin, on 20/4/2017, a clear drop is noted. After suspending escitalopram due to repeated elevation, on 6/5/20I7, the enzymes fell again, and oxybutynin was started on the same day. Within a week, elevation of liver enzymes occurred again, so oxybutynin was suspended on I5/5/20I7 and the enzymes started to fall reaching baseline values in the following few days.

Abbreviations: ALT, alanine aminotransferase; AST, aspartate aminotransferase.

have been sufficiently anonymized and approval for publication has been obtained from the organization's medical research center.

\section{Discussion}

Oxybutynin-induced elevation in liver enzymes is not reported in literature. To the best of our knowledge, this is the first published report on oxybutynin-induced elevation in liver enzymes. The time course of oxybutynin prescription and discontinuation and the accompanying fluctuations in liver enzymes points out a probable adverse drug reaction (ADR).

To rate this suspected ADR, Naranjo scale was used. Naranjo scale is an ADR probability scale which was developed in 1991 by Naranjo et $\mathrm{al}^{13}$ from the University of Toronto. This scale consists of 10 questions that are answered as either "Yes/No," or "Do not know." Different point values $(-1,0,+1$ or +2$)$ are assigned to each answer. A score of 6 was obtained by Naranjo scale, indicating a probable oxybutynininduced liver injury ${ }^{15}$ (Table 1).

Atorvastatin may induce idiosyncratic liver injury. However, it is rare but can be severe. ${ }^{16,17}$ In a meta-analysis conducted by Denus et al, ${ }^{20}$ the proportion of patients having liver function test abnormalities was low in both groups treated with statins and placebo (statins $1.14 \%$ vs placebo 1.05\%, odds ratio: $1.26,95 \% \mathrm{CI}$ : $0.99-1.62, P=0.07) .{ }^{18}$ Although atorvastatin can cause increase in the levels of

Table I Naranjo adverse drug reaction scale

\begin{tabular}{|c|c|c|c|c|}
\hline \multicolumn{5}{|l|}{ ADR probability scale } \\
\hline Question & Yes & No & $\begin{array}{l}\text { Do not } \\
\text { know }\end{array}$ & Score \\
\hline I. Are there previous conclusive reports on this reaction? & +1 & 0 & 0 & 0 \\
\hline 2. Did the adverse event appear after the suspected drug was administered? & +2 & -1 & 0 & +2 \\
\hline 3. Did the adverse event improve when the drug was discontinued or a specific antagonist was administered? & +1 & 0 & 0 & +1 \\
\hline 4. Did the adverse event reappear when the drug was re-administered? & +2 & -1 & 0 & 0 \\
\hline 5. Are there alternative causes that could on their own have caused the reaction? & -1 & +2 & 0 & +2 \\
\hline 6. Did the reaction reappear when a placebo was given? & -1 & +1 & 0 & 0 \\
\hline 7. Was the drug detected in blood or other fluids in concentrations known to be toxic? & +1 & 0 & 0 & 0 \\
\hline 8. Was the reaction more severe when the dose was increased or less severe when the dose was decreased? & +1 & 0 & 0 & 0 \\
\hline 9. Did the patient have a similar reaction to the same or similar drugs in any previous exposure? & +1 & 0 & 0 & 0 \\
\hline 10. Was the adverse event confirmed by any objective evidence? & +1 & 0 & 0 & +1 \\
\hline
\end{tabular}

Note: This suspected ADR is rated as "probable."

Abbreviation: ADR, adverse drug reaction. 
AST and ALT, it was discontinued and liver enzymes dropped accordingly before they rose again after oxybutynin was started.

Escitalopram is considered one of the antidepressants with least potential for hepatotoxicity. ${ }^{19,21}$ In this case, it was ruled out as the cause of the latest elevation in liver enzymes as the latter dropped after it was discontinued even before oxybutynin was started.

\section{Conclusion}

Our findings suspect a correlation between oxybutynin and elevations in liver enzymes. However, further controlled trials are demanded to confirm this probable ADR.

\section{Disclosure}

The authors report no conflicts of interest in this work.

\section{References}

1. Mehdi Z, Birns J, Bhalla A. Post-stroke urinary incontinence. Int J Clin Pract. 2013;67(11):1128-1137.

2. Brittain KR, Peet SM, Castleden CM. Stroke and incontinence. Stroke. 1998;29(2):524-528.

3. Agency for Health Care Policy and Research (APCHR). Urinary Incontinence Guideline Panel. Urinary Incontinence in Adults: Acute and Chronic Management. Clinical Practice Guideline. Rockville, MD: US Department of Health and Human Services; APCHR publication no. 96-0682; 1996.

4. Abrams P, Cardozo L, Fall M, et al; Standardisation Sub-Committee of the International Continence Society. The standardisation of terminology of lower urinary tract function: report from the Standardisation Subcommittee of the International Continence Society. Neurourol Urodyn. 2002;21(2):167-178.

5. Nabi G, Cody JD, Ellis G, Herbison P, Hay-Smith J. Anticholinergic drugs versus placebo for overactive bladder syndrome in adults. Cochrane Database Syst Rev. 2006;(4):CD003781.

6. Bettez M, Tu le M, Carlson K, et al. 2012 update: guidelines for adult urinary incontinence collaborative consensus document for the Canadian urological association. Can Urol Assoc J. 2012;6(5):354-363.
7. Yamaguchi O. Antimuscarinics and overactive bladder: other mechanism of action. Neurourol Urodyn. 2010;29(1):112-115.

8. Hughes KM, Lang JC, Lazare R, et al. Measurement of oxybutynin and its $\mathrm{N}$-desethyl metabolite in plasma, and its application to pharmacokinetic studies in young, elderly and frail elderly volunteers. Xenobiotica. 1992;22(7):859-869.

9. Garely AD, Burrows LJ. Current pharmacotherapeutic strategies for overactive bladder. Expert Opin Pharmacother. 2002;3(7):827-833.

10. Ioannou GN, Boyko EJ, Lee SP. The prevalence and predictors of elevated serum aminotransferase activity in the United States in 1999-2002. Am J Gastroenterol. 2006;101(1):76-82.

11. Bernal W, Wendon J. Acute liver failure. N Engl J Med. 2013;369(26): 2525-2534.

12. Sgro C, Clinard F, Ouazir K, et al. Incidence of drug-induced hepatic injuries: a French population-based study. Hepatology. 2002; 36(2):451-455.

13. Naranjo CA, Busto U, Sellers EM, et al. A method for estimating the probability of adverse drug reactions. Clin Pharmacol Ther. 1981;30(2):239-245.

14. Björnsson ES, Bergmann OM, Björnsson HK, Kvaran RB, Olafsson S. Incidence, presentation, and outcomes in patients with drug-induced liver injury in the general population of Iceland. Gastroenterology. 2013;144(7):1419-1425.

15. Chang CY, Schiano TD. Review article: drug hepatotoxicity. Aliment Pharmacol Ther. 2007;25(10):1135-1151.

16. Health Canada. Canadian Adverse Drug Reaction Monitoring Program Database. Ottawa, ON: Health Canada. Available from: http://cvp-pcv. hc-sc.gc.ca/arq-rei/index-eng.jsp. Accessed April 27, 2018.

17. LiverTox [webpage on the Internet]. Adverse Drug Reaction Probability Scale (Naranjo); 2017. Available from: https://livertox.nih.gov/Narajo. html. Accessed January 9, 2018.

18. Björnsson E, Jacobsen EI, Kalaitzakis E. Hepatotoxicity associated with statins: reports of idiosyncratic liver injury post-marketing. J Hepatol. 2012;56(2):374-380.

19. Hey-Hadavi JH, Kuntze E, Luo D, Silverman P, Pittman D, Lepetri B. Tolerability of atorvastatin in a population aged $\geq 65$ years: a retrospective pooled analysis of results from fifty randomized clinical trials. Am J Geriatr Pharmacother. 2006;4(2):112-122.

20. de Denus S, Spinler SA, Miller K, Peterson AM. Statins and liver toxicity: a meta-analysis. Pharmacotherapy. 2004;24(5):584-591.

21. Voican CS, Corruble E, Naveau S, Perlemuter G. Antidepressantinduced liver injury: a review for clinicians. Am J Psychiatry. 2014; 171(4):404-415.
Therapeutics and Clinical Risk Management

\section{Publish your work in this journal}

Therapeutics and Clinical Risk Management is an international, peerreviewed journal of clinical therapeutics and risk management, focusing on concise rapid reporting of clinical studies in all therapeutic areas, outcomes, safety, and programs for the effective, safe, and sustained use of medicines. This journal is indexed on PubMed Central, CAS,

\section{Dovepress}

EMBase, Scopus and the Elsevier Bibliographic databases. The manuscript management system is completely online and includes a very quick and fair peer-review system, which is all easy to use. Visit $\mathrm{http}: / /$ www.dovepress.com/testimonials.php to read real quotes from published authors. 